SB 411

. 553

Copy 1 



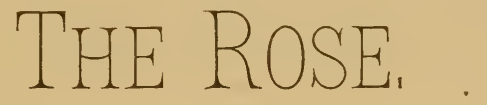

-

HISTORICAL AND DESCRIPTIVE;

GATHERED

FROM VARIOUS SOURCES.

$\frac{13}{8^{3}} 4$

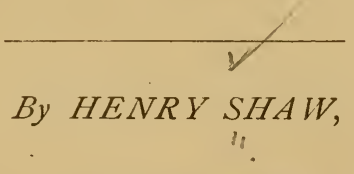

TOWER GROVE.

\section{SAINT LOUIS:}

R. P. Studley \& Co., Printers and Binders. 1879. 



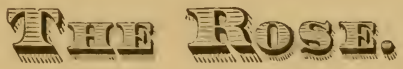

RosA, from rhos, red, in the language of Armorica, (a province of ancient Gaul.)

RoDon, Greek, and

Rosa, Latin.

\section{Iftstancisad.}

$\stackrel{\text { t }}{\text { III }} \mathrm{HE}$ ROSE has been a favorite flower from time immemorial. among the civilized nations of Europe and Asia. Many ages ago Anacreon sang the praises of the Rose. He calls it "the most beautiful of flowers," "the delight of the gods," "the favorite of the Muses," and since that time it has been denominated the Queen of Flowers. It is frequently spoken of in Holy Writ, and Homer often refers to the Rose, both in the Iliad and the Odyssy. It may be said to be the oldest of celebrated flowers, 
and, in the impassioned strains of the ancients, we find it associated with the Lily of the Valley, as expressive of all that is pleasing to the senses, and renovating to the mind.

In the mythologic ages it was sacred as the flower of young affection and endearment, and of mature love-the flower of Cupid and Venus, and stripping this of the mythological phraseology, which in all cases was a fictitious mantle, thrown around something previously felt, no similitude of any flower could be inore appropriate. The rosebud, the sweetest object that appears in the garden, is typical of all beginnings from the issue of which joy and pleasure may be expected.

"Ah see the Virgin Rose, low sweetly shee Dost first peep forth with bashful modestie, That fairer seems, the less you see her may! Lo! see soon after, how more bold and free Her bared bosom she doth broad display! Lo! see soon after how she facles and falls away !"

Spenser's Faerie Queen-1589.

The early dawn; young schemes and projects; young life; young love, and a hundred other associations, all of a delightful kind, are associated with the Rosebud. There seems a physical attraction in it beyond all 
flowers in every stage of its growth, and an attraction which addresses itself strongly to the feelings. When roses are in full bloom, they certainly are the most delightful flowers the amateur can cultivate; the Rose is the most obedient to his labor, and rewards the cultivator richly for his care and skill. Still, there are persons who share with the black beetle a positive dislike for the Rose. Among those who have taken so prominent a part in public life as to have attracted the attention of history, is the famous Chevalier de Guise, who could not smell a rose without feeling uncomfortable; and Vinieri, one of the Doges of Venice, suffered under the same inconvenience for the enjoyment of the garden. Anne of Austria, wife of Louis XIII, could not even look at a rose in a picture without being seized with tantrums.

In the East there is still the belief that the first Rose was formed by a tear of the Prophet Mahomet, but nations of more cool and dispassionate imaginations have sometimes admitted that its origin was lost in obscurity. Roses were used in very early history among the most potent ingredients of love philters. They seem to have been imported by the Romans from Egypt until the age of Domitian. 
Antiochus slept upon a bed of rose leaves; Mark Anthony begged that Cleopatra would cover his tomb with these flowers, and, mea rosa was a favorite term with Roman lovers. Homer has adorned the shield of Achilles, and the helmet of Hector with roses. Among the Greeks it was customary to leave bequests for the maintenance of rose gardens over the grave of the testator, and at 'Torcallo, near Venice, an inscription may still be seen, which shows that the fashion was adopted in Italy. In Turkey, a stone rose is often sculptured above the graves of unmarried women. A charming bas-relief on the tomb of Madame de la Live, who died at the age of twentyone, represents Time mowing a Rose with his scythe.

Acenriling to Indian mythology, Pagodastri, one of the wives of $\mathrm{Vishnu}$, was found in a rose. Zoroaster is said to have matle a rose-tree spring out of the earth and bud and bloom in the presence of Darius, who had called upon him to perform a miracle. In one of the books attributed to Solomon, eternal wisdom is compared to rose-trees at Jericho. Princess Nollmahal, the most lovely lady in the harem of the Great Mogul, had a canal filled with rose-water. and rowed about in it with her august consort, the heat of the 
sun disengaged the essential oil from the water, and their majesties having observed the fact, invented Otto of Roses. When the Soldan, Saladin, who had so much trouble with our hard-fisted King Richard, and his turbulent christian friends, took Jerusalem in 1188, he would not enter the Temple, which he profanely called a mosque, until he had its walls washed with rose-water; and Samet assures us that five hundred camels were no more than sufficient to carry the purifying thuid. Also after the taking of Coustantinople by Mahomet II, in 145\%, the chureh of Saint Sophia was solemnly purified with rose-water before it was converted into a mosque. The high priest of the Hebrews wore a crown of roses when he offered up certain sacrifices under the Mosaic dispensation, and it was perhaps in remembrance of this fact, that the Synod of Nismes, which was held in the third century, enjoined every Jew to wear a rose on his breast, as a distinguishing mark of his inferiority. In many countries, the Jews still celebrate the festival of Eastern Flowers; during which they ornament their lamps, chandeliers and beds with roses.

When Maria Antoinette passed through Nancy, on her way to be married to Lewis XVI, the ladies of 
Lorraine prepared her a bed strewed with roses. In the middle ages roses were held so precious in France that a royal license was necessary to grow them; Charlemagne, recoinmended the cultivation of the Rose in his "Capitulation." The Persians of Shiraz stop their wine bottles with roses to give the wine a pleasing perfume; and during the festival of Abrizan, which takes place during the equinox, Persian ladies throw roses at each other when they visit. "On entering the gardens of the royal palace of Persia," says Sir Robert Porter, "you are struck with the appearance of rose-trees full fourteen feet high, laden with thousands of roses, blooming and diffusing a delicacy of perfume, that imbued the whole atmosphere; but in these delicious gardens of Negaristan, the eye and the olfactories are not the only senses regaled by the presence of the Rose; the ear is enchanted by the wild and beautiful notes of multitudes of nightingales, whose warbling seem to increase in melody and softness with the unfolding of their favorite flowers. Here, indeed, is the genuine country of the nightingale and the Rose.

At Rome the Golden Rose was consecrated by the Pope and given to some prince or princess as a mark 
of the Sovereign Pontiff"s favor. Urban V gave the Golden Rose to Joan, Queen of Sicily, in 1368. Henry VIII of England received a golden Rose from Julius II, and from Leo $\mathbf{X}$. Roses were often, in the days of chivalry, worn by the cavaliers in tournaments, as an emblem of their devotion to love and beauty.

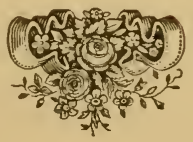





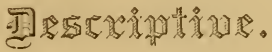

$\stackrel{\text { t }}{1}$ HE habits and colors of the several varieties of the Rose are almost without end, and yet there is great beauty in each of them. Then the perfume with which they embalm the zephyr, as it plays gently over them, diffusing an odor most delightful to the sense, and exhilarating to the mind. In most instances the odor of a flower dies along with it, but not so with the Rose, for some leaves gathered by the writer at Tower Grove, in 1852, and preserved in a jar, are now, (1877), still fragrant. We find it yielding a variety of fragrant liquors, and the attar of roses especially, when prepared in the valley of the Ganges, or in Cashmire, where square miles are devoted to the growth of this tlower, is now almost the only substance which, weight for weight, is more valuable than gold. 
The shrub varies in size, usually from one to six or eight feet; the colors are red, white, yellow, purplestriped, and in almost numberless shades and varieties; the flowers single, semi-double and double; the odor is universally grateful; the green rose is a monstrosity, without fragrance.

The Rose is cultivated in every garden, from that of the most humble peasant to that of persons of rank and wealth, but, will not grow to perfection in the smoky, dusty atmosphere of large towns. Some species. as Rosa centifolia, damascena, \&c., are also cultivated by commercial gardeners, on a large scale, for distilling rose-water, or for making attar or essential oil of Roses; six pounds of rose-leaves will impregnate, by distillation, a gallon of water strongly, with their odor, but a hundred pounds affords scarcely half an ounce of attar. This most delicious of all perfumed essences is obtained by the simple distillation of rose-leaves. In our climate Roses are not sufficiently scented to produce the odoriferous essential oil. Among the most favorable countries for the production of the most highly scented Roses is the middle portion of European Turkey, at the base of the southern slope of the Bal- 
kan mountains, in localities where the Roses are protected against all winds except those from the south; and the flowers thus attain a luxuriance of perfume and growth peculiar to these favored regions. The center of the cultivation and distillation of the Rose is the town of Kezanlik, situated in the province of that name, and is watered by many mountain streams that furnish a suitable water for the distillation of the precious attar. The numerous villages of the province, inhabited by Turks and Christians employed in the cultivation of the Rose, all live in peace together and prosper; finding by experience that it is better and more wise to work, than to waste time in religious and political quarrels. 'The great harvest commences May 15th, and lasts until June 5th or 10th; the gathering is done in the morning before sun-rise, so as to have the benefit of all the fresh perfume of the flowers, which might be drawn off by the heat of day. Every Rose farmer bas his own small, roughly constructed stills for producing the otto or attar immediately after picking the flowers; and thousands of industrious workers are thus occupied, earning in the single short period of twenty days the product of a year's labor, cultivating and taking care of the growing plants. The 
total yearly production of the province of Kazanlik is from 3500 to 6000 pounds, the product of 1866 . but in 1872 only 1700 pounds could be obtained. When distillation is over, the farmers come to the great commercial centers of Constantinople and Adrianople to sell their products.

Unfortunate Kazanlik! ravaged by the horrors of war; in place of quiet villages reposing in the valleys of the Balkans, presents at this time (1877) a scene of ruin and devastation; the dwellings of the inhabitants the churches of the Christians, and the mosques of the Moslem, are now heaps of smouldering ruins. The Rose cultivators slanghtered, fled, or suffering from pestilence and famine; the Rose gardens, once so delightful, are now overrun by hordes of Muscovite soldiers, or serve as pens for the horses of the Cossack. 


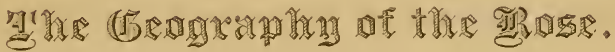

征藏 OSES in a wild state are natives of Persia, India IIII China, Barbary, Europe, and North America, and confined to the northern hemisphere, never having been found wild very near to, or south of the Equator. The vast continent of Australia, rich in botanical treasures as it is, has not yet revealed to us a single species.

Among the wild roses of North America are Rosa Hudsonensis, found on the shores of Hudson's Bay, within the polar circle, where it produces clusters of double pale flowers. Rosa lucida is found in the marshes of Carolina. Rosa Woodsii is found on the banks of the Missouri along with $R$. Carolina. Rosa evratina grows on the marshy banks of the rivulets of Virginia, and is extremely difficult of culture in gardens. Rosa parrifolia is a diminutive shrub found on the rising grounds of Pennsylvania. Rosa setigera is 
found in South Carolina, and R. lavigata, a climbing species, inhabiting the woods of Georgia, and was used by the dusky belles of the forest to adorn their hair. The Rose of Mexico, Rosa Montezuma, is a sweet scented thornless species, which abounds in the parts of Cerro Ventoso, near San Pedro, where it was discovered by Messieurs Humboldt and Bonpland.

Asia can boast of a greater number of species of the Rose than the rest of the earth united, thirty roses that admit of accurate definition having been alleady established. Of these the vast empire of China, where both agriculture and horticulture are arts in high estimation, has a claim to fifteen. The southern provinces of Asia, comprising those of India, offer many curious species to our observation. In the gardens of Kandahar, Samarcand, and Ispahan, the Rosa arborea is cultivated in great profusion by the Persians; this shrub, which attains a consiclerable size, is covered during spring with an abundance of white and scented blossoms.

The Rosa Damascena, transported to Europe from Damascus by the Crusaders, affording to our gardens an infinite number of beautiful varieties, adorns the 
sindy deserts of Syria with its sweet and brightly tinted flowers.

In Europe even Iceland and Lapland produce the Sweet Briar, blooming almost under the snows of those severe climates. Six species are indigenous to Britain, including the well known Dog Rose. The Swiss mountains and Alpine chain are in general rich in native roses. In the eastern and southern countries of Europe, rose trees abound; Italy and Spain have several distinct species. 'The Rosa sempervirens, common in the Balearic Islands, grows spontaneously throughout the south of Europe, and in Barbary, its foliage of glossy green, is intermingled with a profusion of small white highly scented flowers.

For France nimeteen are claimed by the Flora of Decandolle; in the southern provinees is found $R$. Eglantina, whose golden petals are sometimes varied into a rich orange. In the forests of Auvergne we find the Rosa cinnamomum, which derives its name from the color of its branches; its flowers being small, red and solitary; the Champigne Rose, a beautiful miniature shrub, adorns the fertile valleys in the neighłborhood of Dijon, with its very double but small 
crimson blossoms, and the Rosa Gallica, is one that has afforded varieties of every hue, including the Province Roses, white, pink, and erimson.

The genus Rosa comprises about a hundred distinct species, a few of which and their varieties, are grown in the Missouri Botanical Garden.

Rosa bracteata.-The Macartney Rose.

"6 spinosissima.-The Scotch Rose.

" lucida.-Whe Burnett Rose.

" Centifolia.-The hundred-leaved or Cabbage Rose; its varieties include the Single and Double Moss and the White Moss Rose. Provins Roses are of this class.

" Hibernica.-The Irish and R. Lutea, the Yellow Rose.

"rubiginosa.-The Eglantine or Sweet Briar.

$\therefore \quad$ Indica.-The common China, or monthly Bengal which has many varieties.

" Indica odorata.-The tea scented; of this class are the popular Marshal Neil and Duchess of Edinburg Roses.

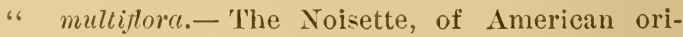
gin.

"B Bankisia.-Rosa galica, the French. 
Rosa Bourboniana-Isle of Bourbon Roses. Some of the most beautiful of Autumnal Roses belong to this class, the Autumn indeed being their peculiar season. The first plant was introduced to France in 1822, and having attracted the attention of the leading rose growers of Paris, they set to work and propagated it extensively. From July to September they are constantly in bloom at Tower Grove.

Climbing Roses are Rosa sempervirens, Rosa arvensis, the Ayrshire, Ruga, Multiflora, Rosa Russelliana, the Boursault Rose; among the American species is the Prairie Rose. Rosa setigera of Michaux, a splended native rose of the Southern and Western States, of which about twenty varieties are in cultivation.

Rosa Hibernica, with prickles of stem, rather hooked, leaflets eliptical, smooth. Discovered and described by John Templeton, Esq., in the county of Down, about Belfast harbor, where it grows abundantly, flowering from the early part of June to the middle of November. The discoverer of this Rose, thus became entitled to the liberal reward of $£ 50$ offered by the patrons of botany at Dublin, for the discovery of any new Irish plant. The stem is six feet high, 
and much branched; flowers pale blush colored; fruit scarlet, smooth ant globose. Doctor Taylor also found other native Irish Roses of distinct species. The sweet briar, or Eglaritine of the poets, has the under leaflets clothed with reddish viscid glands, the seat of a delightful fragrance. Almost all the cultivated open ground sorts delight in a rich moist soil, and an open situation free from smoke and dust, where they are much finer than when they are upon a dry soil or in a shady situation.

Rosa Laurenciana, Fairy roses. 'These beantiful little plants of sixteen rarieties, are well worthy our attention, from their dwarfuess and perfect symmetry of form, often flowering when not more than six inches high, and for the beautiful color of their diminutive rosebuds; they are named in honor of Miss Lawrence who published in 1799 a collection of engravings of the Rose accurately drawn, and elegantly colored; this lady's name is perpetuated in this class, Laurenciana. Rosa moschata, the Musk Rose, a very beautiful class of single Roses, very fragrant with flowers in bunches. The musky odor is rery perceptible, even at some distance from the plant, particularly in the evening. 
"When each inconstant breeze that blows, Steals essence from the musky Rose."

It was formerly much valued for its fragrance when musk was a fashionable perfume.

Loudon gives the description of 97 distinct species, and the names of 468 varieties that he had seen in cultivation in 1840 .

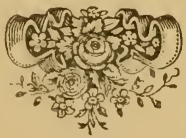





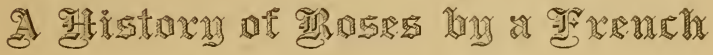

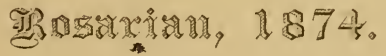

IXTY years ago the Rose list of Decemet was न considered very full; it included 300 roses. In 1830 we knew about 2,500 varieties; we have now more than double that number, and this fact is mainly owing to the seedlings by hybridisations, and the intelligent selections of French florists.

If France is not the native country of the Rose which like the vine was born in Asia, it is in France that the vine and the Rose have found the soil, the climate and the care which have made their fortunes. More than 5000 Roses! and how many simple admirers of nature, with the poets at their head, seem to think them only one; the Rose of Homer, of Virgil, of Delille, and of St. Lambert. But of the poets' Rose we have no picture, no actual record. There is 
erers reason to suppose howerer. it was the Rosa centifolia. the Hundred-leared Rose, which the poets sang. and it was almost the only one to which the painters paid homage: since Redoutè (a celebrated painter of flowers their pencils hare delineated mant of the lorely rarieties which our gardens hare produced: but look at the paintings of the 16 th. 17th and 1 th centuries. and you will see none but the Cabbage (100-leared) Rose, the English White and Red Roses of York and Lancaster and the Yellow Rose which onlt became really double about a hundred years since. We must admit the Cabbage Rose. as the Dutch formed it, has never ret been surpassed br any of the productions of our florists, none had even approached it: and it has the advantage of flowering twice a rear like the Roses of Prstum, which were probably a kind of four seasons Rose. In almost every country these roses are apparently as old as the bills: but it is from the $A$-iatic hundred-petaled rose tribe that man has everywhere his first delight.

The Pose of Prorence. down to the time of the crusades at least. the only famous rose in France, was the first of these oriental risitors acclimated amongst us; the Pose of Damascus. which has much of their 
blood in its reins, was brought to France it is said by the Count De Brie. and the neighborhood of Brie. Conte Robert. is still the great field from which France supplies Europe and America with rose trees. The old English Rose was a daughter or cousin to the Prorence Rose. Their Portland itself is a species of Cabbage Rose. Centfeuilles-what rendered it famous was its flowering twice. Where did the Dutch find the true hundred petaled Rose? Perhaps. like us. they got it from the Moors in Spain. or the merchants of Smyrna. Wherever the obtained the original. it was their art which dereloped all its beauties.

Till nearly the end of the reign of Louis the XIV the gardens of Europe depended upon the same souree-improving the known varieties bs grafting. without raising seedlings. and making seareels any new acquisitions. In 1735 the Fairs Rose. Pompon. was discorered in a wood near Dijon: it was not of much beauty then. The Moss Ruse. issue of the Cabbage Rose, appeared about the same time. It is thought that Uiller. the learned English gardener ob. tained it in $17-7$. The Countes: de Genlis introdnced it into Paris about twenty rears arter that date.

But an unexpected era was now approaching. All 
wras changed when the Tea Rose reached us from China, and the Bengal Rose from India. These precious shrubs, near relations, however, of the Dog Rose of our own woods, were the richest presents that the soil of India could give us. We possessed the finest of roses, but they only blossomed during a few days at the end of the spring; the new comers decorated our gardens to the end of autumn with an abundance and freshness of foliage and flowers hitherto unapproached.

These were. however, only half the treasures scattered by Flor:a over the gardens which she loves. The marriage of the old with the fruitful young rose was soon consummated. and from that time the wand of the fairy multiplied the beanties in the hands of our ablest florists. Hybridisation, and seedlings aiding each other, there is scarcely a limit to the caprice of the most daring eultivator.

It was about 1789 that the Bengal and Tea Roses became well known. The Banksian climbing Rose was only bronght from China in 1807 . The Bourbon Rose appeared somewhat later; the Noisette had then already arrived from America. 
Let us not be ungrateful to our old roses; at the very moment when an unknown field was opened up to us in the East, the Portland, cultivated by Mons. Telieur, of Ville sur Ars, or perhaps by Mons. Souchet, gave us that adınirable Rose du Roi, so vigorous, so hardy, so well formed. so delicious in color and perfume.

The free-flowering Rose of China, bloomed for the first time in France in 1812; the English knew it before that date; how many names and dates shonld we have to inscribe, to perpetuate the memory of the conquests of the Rosary during the last fifty or sixty years?

Many exquisite beauties have been brought by the art of man from beneath the veil which nature had thrown over them; but the most splendid remains yet to be discovered. and the victory is not hopeless; this is not the Blue Rose but the climbing Cabbage Rose. A simple amateur discovered the Rose du Roi; this ought to give hope to every one who possesses a garden, and a little leisure to cultivate the worship of Flora. 
A rural feast of some parts of France is called the festival of the Roses, in which the best behaved maiden of the town or village is annually crowned with Roses. The Persians have also an annual festival of Roses, which consists of bands of youths parading the streets with music, and offering Roses to all they meet. for which they receive a trifling gratuity. Rarities in Roses are held in high estimation all over the world. At the Botanical Garden of the East Indian Island of Java. Dr. R. H. Scheffer, the Director. states that there the 'Teas, Noisettes and Bourbons grow well, and are always in bloom without ceasing. 'i'he Hybrid Perpetuals flower best on the hills. 'The rich Chinese residing' in Java are great Rose buyers, and do not mind paying 25 florins for a young plant of the Green Rose, or for a Marshal Neil.

War of the Roses in English history, the well known feuds that prevailed between the houses of York and Lancaster, are so ealled from the emblems adopterl by their respective partisans; the adherents of the house of York having the white, those of Laneaster the red Rose, as their distinguishing symbol. These wars originated with the descendants of Ed- 
ward the III, and after extending over a period of eighty years, during which England formed an almost uninterrupted scene of bloodshed and devastation, were finally put an end to by the victory of Henry Tudor, Earl of Richmond, over Richard III in 1485. The victor uniting in his own person the title of Lancaster through his mother, and that of York by his marriage with the daughter of Edward VI. Since that period the Rose has been the emblem of England, as the thistle and shamrock are respectively the symbols of Scotland and Ireland. 
LIBRARY OF CONGRESS

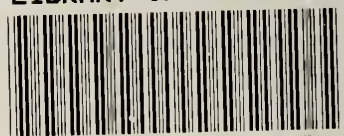

00009200083 